\title{
Choosing footbridge or signalized crossing in an urban area: what triggers pedestrians?
}

\author{
Maria Ourania Skandami, Iliani Styliani Anapali, Socrates Basbas \\ School of Rural \& Surveying Engineering, Aristotle University of Thessaloniki, 54124 Thessaloniki, Greece
}

\begin{abstract}
Pedestrians face difficulties when trying to cross a road in the urban environment since they are exposed to vehicular traffic. One of the measures to overcome the problems in the case of multilane roads with high traffic volumes is the construction of footbridges. However, pedestrians are not always in favor of footbridges for various reasons (e.g., excessive effort to use the footbridge, deviation from their scheduled route etc.). Thus, pedestrians often face a dilemma, whether to use the footbridge or the signalized crossing. In the framework of this paper an attempt has been made to examine the factors that influence the use of footbridges in the urban environment and the factors that influence the use of signalized crossings in the near area of the footbridge. The case study refers to a major arterial road with heavy traffic volumes in the city of Thessaloniki, Greece. A statistical model was

calculation revealed that interviewees who state that the footbridge is very easy to use are more likely to use the footbridge frequently compared to those who state that the footbridge is not at all or almost at all easy to use. The ordinal regression model predicted 0,2 times higher possibility to use the footbridge seldom when interviewees say that their distance from the footbridge affects a little or a lot their crossing point decision. Finally, amongst other important outcomes, the model revealed that interviewees spotted on the footbridge are more likely to use it regularly, thus using the footbridge is more a habit than a random act. Statistical models of this type may help researchers understand pedestrians' attitudes better and potentially contribute to a far better design of new infrastructures or better management of existing infrastructures, considering the user's point of view.
\end{abstract} developed, quantifying the impact of quantitative and qualitative factors, as well as pedestrians' social characteristics on the frequency of using the footbridge. The study area included two signalized crossings and the footbridge. Pedestrians can choose either the footbridge or the signalized intersections to cross the road. Counts were made concerning traffic volume, vehicle speed and pedestrian flow. A questionnaire-based survey including 130 interviewees was conducted among pedestrians referring to the three ways of crossing the road (2 level crossings and the footbridge). Almost half of the pedestrians (49\%) stated that they never use the footbridge. Most of the responders (87\%) consider the footbridge very safe even though they do not use it. In the analysis made in this paper, an ordinal regression model was developed that utilizes questionnaire survey data and field measurements. The aim of the ordinal regression model is to investigate the variables affecting the operation of the footbridge through measuring the frequency of choosing the footbridge to cross the road. The model indicated that pedestrians aged between 25-39 years old have less possibilities to cross using the footbridge. The odds ratio

KEYWORDS: Footbridge; signalized crossing; questionnaire-based survey; ordinal regression model; pedestrians

\section{INTRODUCTION}

The usage level of a footbridge depends on a combination of variables affecting pedestrians crossing decision. According to a study that developed a logistic regression model the decision regarding crossing mode was predicted by the frequency in which the footbridge is crossed, the perception of footbridge security in relation to crime, the perception of footbridge safety about traffic conflicts, the proximity of the footbridge to the level crossing, and if the pedestrian had experienced an injury during a previous highway crossing (Oviedo-Trespalacios \& ScottParker, 2017). The final choice whether to cross a footbridge or not, depends on the pedestrians' per- 
ception of the advantages and disadvantages it may present. In the framework of the literature review findings, footbridges' advantages and disadvantages are summarized below.

\subsection{Advantages of footbridges}

- Safety. Pedestrians' safety is a major issue worldwide due to high pedestrian death rates in road accidents. In 2011 China recorded 15.562 pedestrian deaths which represent $22.31 \%$ of all road accident deaths (Yordphol \& Qian, 1994). NHTSA (2015) revealed that there were 5.376 pedestrian deaths which constitute $14 \%$ of all road accident deaths in USA during 2015. In Jordan every 24 hours 11 pedestrians lose their lives due to car accidents, a number that constitutes $30 \%$ of all road accident deaths (Abojaradeh, 2013). According to Europa Eurostat, in 2013 pedestrian deaths in Europe reached $21.9 \%$ of all road accidents. During the same year, Netherlands recorded 3.0 pedestrian deaths per 1.000.000 residents, the lowest pedestrian death index in Europe; Romania documented the highest pedestrian death index, namely 36.3 pedestrian deaths per 1.000.000 residents, while Greece listed 13.7 pedestrian deaths per 1.000 .000 residents. The Netherlands presents extremely high density of roads, railway lines, and waterways, thus counts decades of experience building cycling and pedestrian bridges. The low pedestrian death index is a result of a wide range of policies and traffic calming implementation, better walking facilities, including footbridges, and urban design oriented to pedestrians (Pucher \& Dijkstra, 2003). According to Greek Traffic Police statistics, 739 deadly road accidents with 796 victims out of which 128 were pedestrians took place in the country during 2015 . This number illustrates $16 \%$ of pedestrian deaths in road accidents. Level signalized crossings that include traffic indicators, horizontal and vertical signaling are the most frequently chosen by pedestrians to cross a road. Pedestrians' illegal crossing behavior is the main cause of road accidents (Wu et al. 2014). Signalized crossings with unattractive surroundings, disadvantageous traffic light regulations for pedestrians, exceedance of speed limits by car drivers, red light running by car drivers are regarded as inconvenient and dangerous, thus pedestrians avoid to use them (Ausserer \& Kaufmann, 2010). Footbridges constructed at urban roads and highways, contribute to safe crossings as pedestrians are not exposed to potential danger due to vehicle flow. Footbridges separate pedestrians from the road surface, creating crossings where pedestrians and vehicles do not interact. It must be mentioned at this point that although pedestrian safety is a crucial issue in the urban environment, it is not a desirable measure to build footbridges from the pedestrian`s perspective. In terms of sustainable mobility, the overall goal is the removal of vehicular traffic and the promotion of walking, cycling, micromobility and environment-friendly Public Transport modes. Therefore, the construction of a footbridge must not be the only option in urban areas for improving road safety level since sustainable mobility strategies in most cases offer the best approach to deal with the problem. Traffic calming measures for example offer a variety of options to deal with road safety problems in urban areas. We always must remember that streets primarily have to serve the needs of vulnerable road users and not the needs of vehicular traffic.

- Stable vehicle traffic flow. When the vehicle speed and the traffic volume are high, thus vehicle flow should not be interrupted, footbridge usage is suggested. According to ITE (1998), although road lights installation and traffic calming implementation contribute to promoting environmentally friendly means of transportation and safe road crossings for pedestrians, in some cases result in vehicle traffic flow interruption. Footbridges encounter the issue by separating vehicle and pedestrian traffic flow. Some pedestrians, despite having the option of using footbridges, prefer to use level crosswalks or to illegally cross the road (Híjar et al. 2003). A combination of different independent variables, such as environmental, socio-economic and traffic factors, affect pedestrians' decision of the crossing point (Rosenbloom, 2009). 


\subsection{Disadvantages of footbridges}

- Walking distance and Travel time. Pedestrians decision concerning their route choice depends on the distance between their trip origin and destination, the available facilities, the surroundings, the conflicts with other road users, the trip purpose and the surface conditions (Fossum \& Ryeng, 2019). The increase of the walking distance is a potential reason of pedestrians not using footbridges (Räsänen et al. 2007). Most pedestrians tend to choose the shortest path route between an origin and a destination (Shatu et al. 2019). Additional walking distance to cross a road over a footbridge is less appealing than using a signalized crossing when available (Cantillo et al. 1962). Moore (1953) studied footbridges and underground crossings in London locating that $80 \%$ of the pedestrians would choose the safest crossing if its travel time was equal to level crosswalk's travel time. No pedestrian would use a footbridge if its travel time were 1.5 times greater than a level crosswalk's travel time (Moore \& Older, 1965). On average, participants are willing to walk an additional 2.4 minutes to use a signalized crossing and avoid using footbridges, due to the time and effort required to use it, and due to issues of personal security (Anciaes \& Jones, 2018). A study conducted in Ankara city center found that only $6.3 \%$ of the pedestrians use a footbridge when a level crosswalk is located near the bridge (Räsänen et al. 2007).

- Inconvenience in use. FHWA (2006) stated that footbridge location should not cause pedestrians' route deviation. The travel time and the convenience in use are the main criteria of choosing a crossing point (Zacharias, 2001). Inconvenience is an important factor that affects pedestrian behavior; the greater the inconvenience perceived by pedestrians, the larger the number of reported transgressive behaviors (Xu et al. 2018). In Beijing 2/3 of the pedestrians not using aboveground or underground crosswalks perceive walking up and down the stairs a tedious process (Yordphol \& Qian, 1994). Landa-Blanco and Ávila (2020) suggested that $17.27 \%$ of Honduras' public university students do not use the footbridge. Students perceive the signalized crossings more convenient and safer in use. The regression model revealed that being in a hurry, poor infrastructure conditions and pedestrians' effort required for walking up and down the stairs reduce the footbridge's usage rate. Questionnaire study in Jordan presented that $60 \%$ of the responders did not use the bridge due to travel time delays and inconvenience in use (Abojaradeh, 2013).

- Security. Footbridge usage rate depends on pedestrians' personal safety perception and the frequency of its use. Footbridges impose a risk to personal safety (Sinclair \& Zuidgeest, 2016). Although exposed to fast- moving vehicles conflicts, pedestrians prefer to cross Cape Town freeways to avoid criminals. Conversely, in Thailand pedestrians feel secure to cross an eight-lane-road using a footbridge (Sangphong \& Siridhara, 2014).

- Habits. The model developed revealed that footbridge's level of usage depends on pedestrians' habits. Pedestrians visiting Ankara city center regularly do not use the footbridge (Räsänen et al. 2007). Pedestrians familiarized with a certain crosswalk, are more prone to cross illegally in comparison to those crossing for the first time (Mitsutaka \& Toshikazu, 2004).

In the framework of this paper an attempt has been made to examine the factors that influence the use of footbridges in the urban environment and the factors that influence the use of signalized crossings in the near area of the footbridge. The case study refers to a major arterial road with heavy traffic volumes in the city of Thessaloniki, Greece. A statistical model was developed, quantifying the impact of quantitative and qualitative factors, as well as pedestrians' social characteristics on the frequency of using the footbridge. Statistical models of this type may help researchers understand pedestrians' attitudes better and potentially contribute to a far better design of new infrastructures or better management of existing infrastructures, taking into account the user's point of view.

\section{METHODOLOGY}

\subsection{Description of the site}

The objective of the paper is to identify which and to what extend various factors (behavioral, infrastruc- 

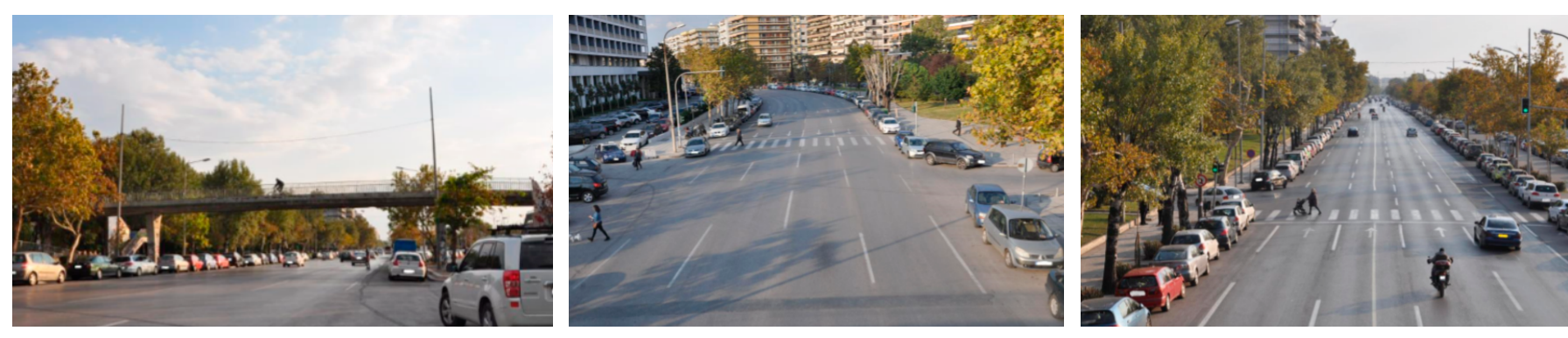

Figure 1. Footbridge; A-signalized crossing, B-signalized crossing (from left to right).

ture and perceptional) are related to pedestrians' decision of crossing or not crossing a footbridge in the city of Thessaloniki, Greece. The population in the regional entity of Thessaloniki according to the 2011 census is around 1,1 million inhabitants. The only Public Transportation system in the city for the moment are buses but a metro system is under completion. Modal split in the city is as follows (Thessaloniki, https://civitas.eu/content/thessaloniki): "The city has a modal split of around $45 \%$ private cars, $27 \%$ public transport, $12 \%$ pedestrians, $7 \%$ taxis, $6 \%$ motorcycles and 3\% private buses". According to the same source, around 1,6 million trips are made daily in the city.

The footbridge under examination was the one located at Megalou Alexandrou Avenue, a coastal road on the eastern side of Thessaloniki, which is characterized by high pedestrian and traffic flows. The footbridge includes stairs and ramps for anode and cathode. Megalou Alexandrou Avenue consists of six traffic lanes, of which the two at the roadside edges are always occupied by illegally parked cars. The right traffic lane mainly serves Public Transportation busses.

Signalized intersections, including signalized crossings, exist on both sides of the footbridge. The intersections' distance equals to 115 meters. The first intersection (A-signalized crossing) is situated at Megalou Alexandrou Avenue and Agias Triados Street. The second intersection (B-signalized crossing), situated at Megalou Alexandrou Avenue and Paraskevopoulou Street, has a pedestrian call button system due to relatively lower pedestrian flows. It must be mentioned at this point that traffic lights in the specific road are coordinated. Figure 1 shows the footbridge at the coastal zone, Megalou Alexandrou Avenue and Agias Triados Street intersection and Megalou Alexandrou Avenue and Paraskevopoulou Street Intersection. Figure 2 shows A-signal- ized crossing, B-signalized crossing and footbridge succession.

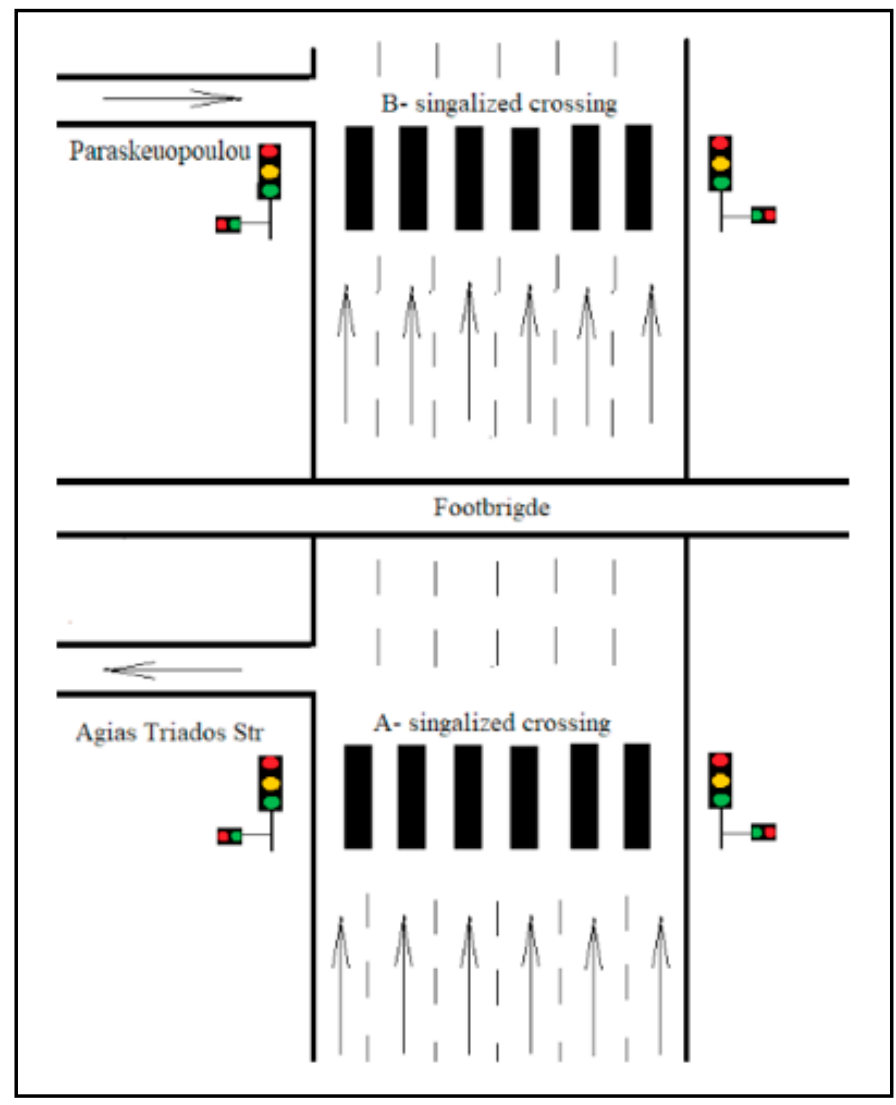

Figure 2. Succession of A-signalized crossing, B-signalized crossing and the footbridge.

\subsection{Questionnaire based survey and counts}

The methodological steps of the undertaken research included the literature review, the selection of the footbridge under examination, the Passenger Car Unit (PCU) and the Peak Hour Factor (PHF) calculation based on vehicle and pedestrian traffic flow counts. The $85^{\text {th }}$ percentile speed (V85), the speed below which 85 percent of vehicles operate under free-flow condition on clean, dry road pavement, was calculated through vehicle speed measurements. The 


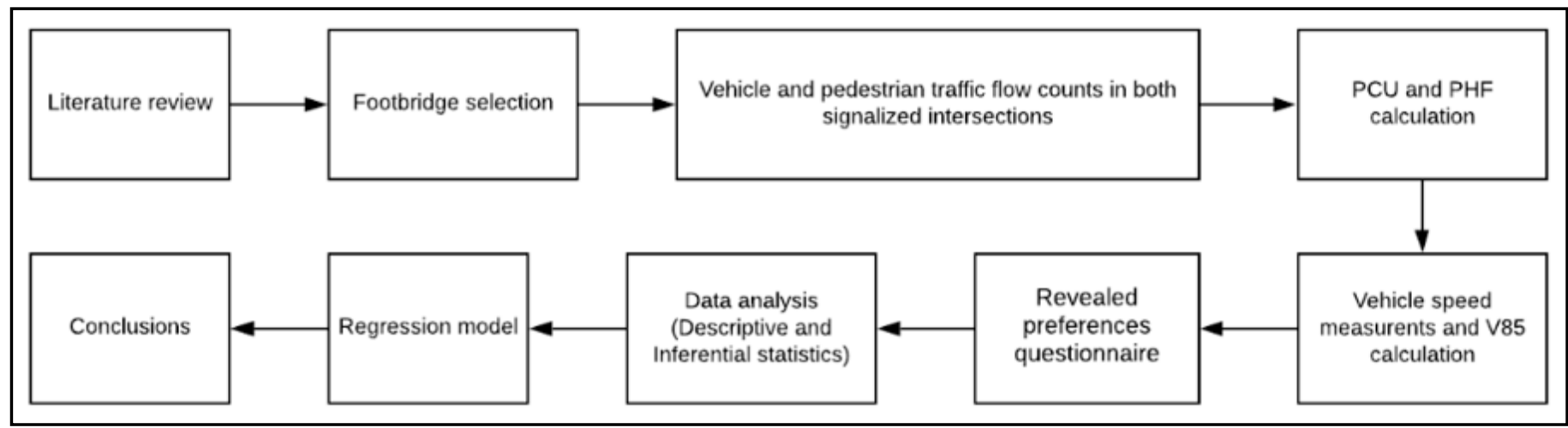

Figure 3. Methodological steps of the undertaken research.

knowledge of the V85 is essential in the road safety investigation (Antonino et al. 2012). The pedestrians' revealed preferences based on the questionnaire survey, the data analysis and the regression model development resulted in the conclusions of the present research. The methodological steps are presented in Figure 3.

Following the literature review and the selection of the footbridge under examination, calculations concerning traffic flows were carried out. It must be mentioned at this point that there were not many options in the city as far as the presence of a footbridge is concerned. The specific footbridge was selected due to the high traffic volumes and the high pedestrian volumes. The Megalou Alexandrou Avenue separates the coastal front from the built-up area of the city. The coastal front attracts a vast number of visitors (i.e., pedestrians, bicyclists) daily. In order to avoid the barrier effect, there are many signalized crossings along the Megalou Alexandrou Avenue but only one footbridge (the one which is examined in the framework of this paper). Pedestrian traffic flow counts conducted in A-signalized crossing, B-signalized crossing and the footbridge, while vehicle traffic flow counts conducted in both signalized intersections. Then, PCU and PHF were calculated. Megalou Alexandrou Avenue presents uniform traffic flow, as the PHF equals to 0.93 and 0.95 for B-signalized and A-signalized intersections, respectively. The traffic composition analysis, based on the PCU, revealed that the majority of the vehicles driving through the intersections are private cars (86\%); Public Transportation busses $(2 \%)$, motorcycles (6\%) and trucks and semi-trucks (6\%).

To determine the 85th percentile speed (V85) at Megalou Alexandrou Avenue, 180 vehicle speeds captured by using the TRUSPEED SE METRIC device. Through linear interpolation V85 calculated at
$60.37 \mathrm{~km} / \mathrm{h}$, while according to the respective signs the speed limit is $50 \mathrm{~km} / \mathrm{h}$. Based on the literature review findings, the possibility of a fatal accident in head-on collision between a vehicle and a pedestrian, reaches $21 \%$ when the vehicle speed is $60 \mathrm{~km} / \mathrm{h}$ (Richards, 2010). According to the British Department of Transport, pedestrian fatality equals to $5 \%$ at $30 \mathrm{~km} / \mathrm{h}$ speed limit, $45 \%$ at $50 \mathrm{~km} / \mathrm{h}$ and $85 \%$ at $65 \mathrm{~km} / \mathrm{h}$ (Cohen et al., 1997; Hussain et al., 2019). It must be mentioned that while $50 \mathrm{~km} / \mathrm{h}$ may be survival for adults and children, the same speed is likely to be fatal for elderly people. Additionally, a collision with a $60 \mathrm{~km} / \mathrm{h}$ running vehicle corresponds to $90 \%$ elderly pedestrians' fatality (Feliciani et al., 2020). Another study suggested that an $8 \mathrm{~km} / \mathrm{h}$ increase in the speed limit is associated with $8 \%$ increase in pedestrian fatality on freeways and $4 \%$ on other roads (Farmer, 2016). An increase of $1 \mathrm{~km} / \mathrm{h}$ at vehicle speed rises the odds of a pedestrian fatality by $11 \%$ (Hussain et al., 2019). A preferred multinomial logit model for the case of North Carolina revealed that the vehicle speed $80 \mathrm{~km} / \mathrm{h}$ and above significantly increases the probability of pedestrian fatalities (Chen \& Fan, 2019).

A revealed preferences questionnaire was randomly distributed to pedestrians crossing A- signalized crossing, B- signalized crossing and the footbridge. The design of the questionnaire was based on the experience of the researchers. The questionnaire structure aimed to provide comprehensible, easy-tounderstand and easy-to-answer questions. The survey was conducted from 11/07/2017 to $18 / 09 / 2017$, by well-trained postgraduate students employing face-to-face interviews, thus achieving high response rate, reliability of the given answers and absence of missing values. Questionnaires distribution followed pedestrians' distribution in the three different crossings according to the pedestrian flow counts. Finally, 
Table 1. Descriptive statistics of the variables.

\begin{tabular}{|c|c|c|c|c|c|}
\hline Description & Values & Measure & Description & Values & Measure \\
\hline First section & & & Second section & & \\
\hline $\begin{array}{l}\text { Gender of } \\
\text { interviewee }\end{array}$ & 1: Male, 2: Female & Nominal & $\begin{array}{l}\text { Crossing a signalized } \\
\text { crossing }\end{array}$ & $\begin{array}{l}\text { 1: During green light phase, } \\
\text { 2: During red light phase, } 3 \text { : Any } \\
\text { time }\end{array}$ & Nominal \\
\hline $\begin{array}{l}\text { Age of } \\
\text { interviewee }\end{array}$ & $\begin{array}{l}1: 18-24,2: 25-39 \\
3: 40-54,4: 55-64,5:>65\end{array}$ & Ordinal & $\begin{array}{l}\text { Variables affecting } \\
\text { crossings }\end{array}$ & $\begin{array}{l}\text { 1: Traffic volume, 2: Vehicles' } \\
\text { speed, 3: Number of pedestrians } \\
\text { waiting the green light phase, } \\
\text { 4: Distance from crosswalk, } \\
\text { 5: Pedestrians' traffic light phase, } \\
\text { 6: Vehicles' traffic light phase, } \\
\text { 7: Inability to see passing vehicles }\end{array}$ & Nominal \\
\hline $\begin{array}{l}\text { Profession of } \\
\text { interviewee }\end{array}$ & $\begin{array}{l}\text { 1: Employee, 2: Civil } \\
\text { servant, 3: Freelancer, } \\
\text { 4: Unemployed, } \\
\text { 4: University student, } \\
\text { 6: Retired }\end{array}$ & Nominal & $\begin{array}{l}\text { Pedestrians' green } \\
\text { light phase duration }\end{array}$ & 1: Satisfying, 2: Not satisfying & Nominal \\
\hline $\begin{array}{l}\text { Education of } \\
\text { interviewee }\end{array}$ & $\begin{array}{l}\text { 1: Primary school, } \\
\text { 2: Secondary school, } \\
\text { 3: Highschool, } \\
\text { 4: University, 5: Masters, } \\
\text { 6: PhD }\end{array}$ & Nominal & $\begin{array}{l}\text { Awareness of } \\
\text { pedestrians' priority in } \\
\text { signalized crossings }\end{array}$ & 1: Yes, 2: No & Nominal \\
\hline $\begin{array}{l}\text { Monthly } \\
\text { income of the } \\
\text { interviewee } \\
\text { (thousand } \\
\text { Euros) }\end{array}$ & $\begin{array}{l}1: 0-400,2: 401-800 \\
3: 801-1200,4: 1201- \\
1600,5: 1601-2000 \\
6:>2000\end{array}$ & Ordinal & Crossing the road & $\begin{array}{l}\text { 1: From crosswalks, 2: Any other } \\
\text { point }\end{array}$ & Nominal \\
\hline $\begin{array}{l}\text { Availability: } \\
\text { private car, } \\
\text { motorcycle, } \\
\text { bicycle }\end{array}$ & 1: Yes, 2: No & Nominal & $\begin{array}{l}\text { Conflict experience as } \\
\text { pedestrians }\end{array}$ & 1: Yes, 2: No & Nominal \\
\hline Crossing point & $\begin{array}{l}\text { 1: A-signalized crossing, } \\
\text { 2: B- signalized crossing, } \\
\text { 3: Footbridge }\end{array}$ & Nominal & Third section & & \\
\hline Second section & & & $\begin{array}{l}\text { Easiness in using: } \\
\text { A- signalized crossing, } \\
\text { B- signalized crossing, } \\
\text { Footbridge }\end{array}$ & $\begin{array}{l}\text { 1: Very, 2: A little, 3: Moderate, } \\
\text { 4: Almost at all, 5: At all }\end{array}$ & Ordinal \\
\hline Travel profile & $\begin{array}{l}\text { 1: Pedestrian, 2: Pedestrian } \\
\text { with stroller, } 3 \text { : Pedestrian } \\
\text { with child, } 4 \text { : Cyclist, } \\
\text { 5: Cyclist with child }\end{array}$ & Nominal & $\begin{array}{l}\text { Time saving when } \\
\text { crossing: A- signalized } \\
\text { crossing, B- signalized } \\
\text { crossing, Footbridge }\end{array}$ & $\begin{array}{l}\text { 1: A lot, 2: A little, 3: Moderate, } \\
\text { 4: Almost at all, 5: At all }\end{array}$ & Ordinal \\
\hline $\begin{array}{l}\text { Most used } \\
\text { daily mode of } \\
\text { transportation }\end{array}$ & $\begin{array}{l}\text { 1: Private car, } \\
\text { 2: Motorcycle, 3: Bicycle, } \\
\text { 4: Public transportation, } \\
\text { 5: Walking, 6: Other }\end{array}$ & Nominal & $\begin{array}{l}\text { Safety when crossing: } \\
\text { A- signalized crossing, } \\
\text { B- signalized crossing, } \\
\text { Footbridge }\end{array}$ & $\begin{array}{l}\text { 1: Very, 2: A little, 3: Moderate, } \\
\text { 4: Almost at all, 5: At all }\end{array}$ & Ordinal \\
\hline $\begin{array}{l}>10 \text { minutes } \\
\text { daily walking } \\
\text { trips }\end{array}$ & $\begin{array}{l}\text { 1: None, 2: One, 3: Two, } \\
\text { 4: Three, 5: Four, 6: Five, } \\
\text { 7: Six, 8: Ten }\end{array}$ & Ordinal & $\begin{array}{l}\text { Distance from } \\
\text { footbridge affecting } \\
\text { the decision of } \\
\text { crossing point }\end{array}$ & $\begin{array}{l}\text { 1: Very, 2: A little, 3: Moderate, } \\
\text { 4: Almost at all, 5: At all }\end{array}$ & Ordinal \\
\hline $\begin{array}{l}\text { Frequency } \\
\text { of crossing: } \\
\text { A- signalized } \\
\text { crossing, } \\
\text { B- signalized } \\
\text { crossing, } \\
\text { Footbridge }\end{array}$ & $\begin{array}{l}\text { 1: Every day, 2: } 2-3 \text { times } \\
\text { per week, 3: Once per } \\
\text { week, 4: 1-2 times per } \\
\text { month, 5: Rarely, 6: Never }\end{array}$ & Ordinal & $\begin{array}{l}\text { Reasons of using the } \\
\text { footbridge }\end{array}$ & $\begin{array}{l}\text { 1: Convenience in use, time } \\
\text { saving, safety, 2: Stroll, 3: View, } \\
\text { 4: Photographs, 5: Other }\end{array}$ & Nominal \\
\hline
\end{tabular}


130 valid questionnaires were collected, resulting in a margin of error $8.59 \%$ at the significance level $a=5 \%$ (Daniel, 1999; Naing et al., 2006).

The questionnaire consisted of 23 questions allocated in 3 sections. The first section contained 7 questions regarding the socio-economic background of the interviewees; the second section contained 11 questions illustrating the mobility profile of the interviewees and the third section contained 5 questions indicating the easiness in using the three different crossings. Table 1 shows the 23 variables along with a presentation of their measurement scale.

It must be mentioned at this point that the question "if one violated a traffic rule and crossed at red lights" is subjected to the restrictions of social desirability bias which plays a crucial role here since people tend to hide their undesirable behavior. Therefore, the respective results must be considered as not a precise representation of the actual behavior of the respondents.

\section{DATA ANALYSIS}

\subsection{Descriptive statistics}

The sample is well distributed regarding gender; most of the responders are aged between 25- 39 (45\%), while older aged pedestrians participated in lower percentages. Most of the participants are employees (32\%), university students (23\%) or freelancers (16\%). A significant percent of the pedestrians is unemployed (12\%). In almost equal percentages pedestrians have either university education or are high school graduates (41\%), while fewer own master's degrees. The monthly income median is 801- 1200 $€$. More than half of the pedestrians have stated that they have access to a private car or a bicycle (55\%), whereas only few of them own motorcycles (17\%). Additionally, $55 \%$ of the pedestrians use B-signalized crossing, 26\% A- signalized crossing and 19\% the footbridge to cross Megalou Alexandrou Avenue.

Most of the interviewees were pedestrians (73\%); some were pedestrians with strollers, children, or cyclists. Private cars, Public Transportation and walking are the most popular means of daily transportation, while motorcycles or bicycles are less frequently used. On average, pedestrians make three 10-minute daily trips. People crossing B-signalized crossing every day are $15 \%$, a percentage slightly greater than A- signalized crossing (12\%). Only one participant uses the footbridge every day; some pedestrians cross the footbridge rarely and almost half of them never cross it. None of the pedestrians cross the signalized crossings during the red-light phase. Most of the pedestrians wait the green light phase to cross $(77 \%)$, while the rest of them cross anytime during the traffic signal cycle. The variables affecting the crossing decision are the traffic light indicator, vehicle speed and the traffic volume. More than half of the interviewees believe that pedestrians' green light phase is satisfying when crossing Megalou Alexandrou Avenue. Most of the participants (89\%) are aware of pedestrians' priority when crossing a signalized crossing according to the Highway Code regulations. Only 35\% cross the Avenue using the signalized crossings, while $65 \%$ cross from any other random point on the road. Most of the interviewees never had a conflict experience as drivers with other pedestrians (97\%).

More than half of the interviewees believe that A-signalized crossing is "very" or "a little" easy to use; B-signalized crossing is "very" easy, and the footbridge is "a little" easy to use. Pedestrians perceive "moderate" time saving when using A- signalized crossing, "a little" time saving when using B- signalized crossing and "a lot" time saving when using the footbridge. According to the interviewees, A- signalized crossing and B- signalized crossing are "a little" safe while the footbridge is "very" safe to cross. Half of the interviewees stated that their decision regarding the place of crossing the Avenue is not "at all" affected by their distance from the footbridge. Safety (60\%) and stroll (26\%) are the most frequently encountered reasons of using the footbridge. The variables and their frequencies are presented on Table 2.

\subsection{Inferential statistics}

Before the development of the "Frequency of crossing the footbridge" model, a correlation matrix was developed to reveal possible relations among the variables.

Considering the socio-economic characteristics of the interviewees, age $(r=0.177, p<0.05)$ is related to the frequency of crossing the footbridge. The results show that younger aged interviewees tend to use the footbridge more frequently than the older ones. Regarding to the crossing point $(\mathrm{r}=-.307, \mathrm{p}<0.05)$, interviewees located at the footbridge when answering the questionnaire present higher possibility of 
Table 2. Descriptive statistics of the variables.

\begin{tabular}{|c|c|c|c|c|c|c|c|}
\hline Code & Description & Values & Measure & Code & Description & Values & Measure \\
\hline & First section & & & & Second section & & \\
\hline Gender & $\begin{array}{l}\text { Gender of } \\
\text { interviewee }\end{array}$ & 1: Male, 2: Female & $\begin{array}{l}\text { 1: } 40.00 \%, \\
2: 60.00 \%\end{array}$ & Ped_gr_ph & $\begin{array}{l}\text { Pedestrians' } \\
\text { green light } \\
\text { phase duration }\end{array}$ & $\begin{array}{l}\text { 1: Satisfying, } \\
2: \text { Not } \\
\text { satisfying }\end{array}$ & $\begin{array}{l}\text { 1: } 52.83 \%, \\
2: 47.17 \%\end{array}$ \\
\hline Age & $\begin{array}{l}\text { Age of } \\
\text { interviewee }\end{array}$ & $\begin{array}{l}1: 18-24,2: 25-39 \\
3: 40-54,4: 55-64, \\
5:>65\end{array}$ & $\begin{array}{l}1: 24.62 \%, \\
2: 45.36 \%, \\
3: 15.39 \%, \\
4: 10.00 \%, \\
5: 4.63 \%\end{array}$ & Aw_ped_pr & $\begin{array}{l}\text { Awareness of } \\
\text { pedestrians' } \\
\text { priority in } \\
\text { signalized } \\
\text { crossings }\end{array}$ & 1: Yes, 2: No & $\begin{array}{l}\text { 1: } 89.23 \%, \\
2: 10.77 \%\end{array}$ \\
\hline Profession & $\begin{array}{l}\text { Profession of } \\
\text { interviewee }\end{array}$ & $\begin{array}{l}\text { 1: Employee, 2: Civil } \\
\text { servant, 3: Freelancer, } \\
\text { 4: Unemployed, } \\
\text { 5: University student, } \\
\text { 6: Retired }\end{array}$ & $\begin{array}{l}\text { 1: } 32.31 \%, \\
2: 7.69 \%, \\
3: 16.15 \%, \\
4: 12.31 \%, \\
5: 23.08 \%, \\
6: 8.46 \%\end{array}$ & Cross_road & $\begin{array}{l}\text { Crossing the } \\
\text { road }\end{array}$ & $\begin{array}{l}\text { 1: From } \\
\text { crosswalks, } \\
\text { 2: Any other } \\
\text { point }\end{array}$ & $\begin{array}{l}1: 34.62 \%, \\
2: 65.38 \%\end{array}$ \\
\hline Education & $\begin{array}{l}\text { Education of } \\
\text { interviewee }\end{array}$ & $\begin{array}{l}\text { 1: Primary school, } \\
\text { 2: Secondary school, } \\
\text { 3: Highschool, } \\
\text { 4: University, } \\
\text { 5: Masters, 6: PhD }\end{array}$ & $\begin{array}{l}\text { 1: } 1.54 \%, \\
2: 1.54 \%, \\
3: 40.77 \%, \\
4: 42.31 \%, \\
5: 10.77 \%, \\
6: 3.07 \%\end{array}$ & Conf_ped & $\begin{array}{l}\text { Conflict } \\
\text { experience as } \\
\text { pedestrians }\end{array}$ & 1: Yes, 2: No & $\begin{array}{l}1: 6.20 \%, \\
2: 93.80 \%\end{array}$ \\
\hline Income & $\begin{array}{l}\text { Monthly } \\
\text { income of the } \\
\text { interviewee } \\
\text { (thousand } \\
\text { Euros) }\end{array}$ & $\begin{array}{l}1: 0-400,2: 401-800, \\
3: 801-1200,4: 1201- \\
1600,5: 1601-2000, \\
6:>2000\end{array}$ & $\begin{array}{l}\text { 1: } 15.38 \%, \\
2: 29.23 \%, \\
3: 20 \%, \\
4: 11.54 \%, \\
5: 6.92 \%, \\
6: 16.93 \%\end{array}$ & $\begin{array}{l}\text { Conf__ } \\
\text { driver }\end{array}$ & $\begin{array}{l}\text { Conflict } \\
\text { experience as } \\
\text { drivers with }\end{array}$ & $\begin{array}{l}\text { 1: Vehicle, } \\
\text { 2: Motorcycle, } \\
\text { 3: No }\end{array}$ & $\begin{array}{l}1: 1.28 \%, \\
2: 1.28 \%, \\
3: 97.44 \%\end{array}$ \\
\hline $\mathrm{Av} \_p c$ & $\begin{array}{l}\text { Availability: } \\
\text { private car, }\end{array}$ & 1: Yes, 2: No & $\begin{array}{l}1: 55.38 \%, \\
2: 44.62 \%\end{array}$ & & Third section & & \\
\hline Av_mc & motorcycle, & 1: Yes, 2: No & $\begin{array}{l}\text { 1: } 16.92 \%, \\
2: 83.08 \%\end{array}$ & Easiness_A & $\begin{array}{l}\text { Easiness } \\
\text { in using: } \\
\text { A- signalized } \\
\text { crossing, }\end{array}$ & $\begin{array}{l}\text { 1: Very, } \\
\text { 2: A little, } \\
\text { 3: Moderate, } \\
\text { 4: Almost at } \\
\text { all, 5: At all }\end{array}$ & $\begin{array}{l}1: 34.62 \%, \\
2: 20.00 \%, \\
3: 27.69 \%, \\
4: 15.38 \%, \\
5: 2.31 \%\end{array}$ \\
\hline$A v \_b c$ & bicycle & 1: Yes, 2: No & $\begin{array}{l}\text { 1: } 43.08 \%, \\
2: 56.92 \%\end{array}$ & Easiness_B & $\begin{array}{l}\text { B- signalized } \\
\text { crossing, }\end{array}$ & $\begin{array}{l}\text { 1: Very, } \\
\text { 2: A little, } \\
\text { 3: Moderate, } \\
\text { 4: Almost at } \\
\text { all, 5: At all }\end{array}$ & $\begin{array}{l}\text { 1: } 56.25 \%, \\
2: 15.63 \%, \\
3: 27.34 \%, \\
4: 0.78 \%, \\
5: 0.00 \%\end{array}$ \\
\hline \multirow[t]{2}{*}{$\begin{array}{l}\text { Cross_ } \\
\text { point }\end{array}$} & Crossing point & $\begin{array}{l}\text { 1: A-signalized } \\
\text { crossing, } \\
\text { 2: B- signalized } \\
\text { crossing, } \\
\text { 3: Footbridge }\end{array}$ & $\begin{array}{l}1: 26.15 \%, \\
2: 55.38 \%, \\
3: 18.47 \%\end{array}$ & $\begin{array}{l}\text { Easiness_ } \\
\mathrm{Fb}\end{array}$ & Footbridge & $\begin{array}{l}\text { 1: Very, } \\
\text { 2: A little, } \\
\text { 3: Moderate, } \\
\text { 4: Almost at } \\
\text { all, 5: At all }\end{array}$ & $\begin{array}{l}1: 42.06 \%, \\
2: 13.49 \%, \\
3: 23.81 \%, \\
4: 11.90 \%, \\
5: 8.74 \%\end{array}$ \\
\hline & $\begin{array}{l}\text { Second } \\
\text { section }\end{array}$ & & & $\begin{array}{l}\text { Time__ } \\
\text { Sav_A }\end{array}$ & $\begin{array}{l}\text { Time saving } \\
\text { when crossing: } \\
\text { A- signalized } \\
\text { crossing, }\end{array}$ & $\begin{array}{l}\text { 1: A lot, } \\
\text { 2: A little, } \\
\text { 3: Moderate, } \\
\text { 4: Almost at } \\
\text { all, 5: At all }\end{array}$ & $\begin{array}{l}1: 19.23 \%, \\
2: 26.92 \%, \\
3: 31.54 \%, \\
4: 13.85 \%, \\
5: 8.46 \%\end{array}$ \\
\hline Trv_prof & Travel profile & $\begin{array}{l}\text { 1: Pedestrian, } \\
\text { 2: Pedestrian with } \\
\text { stroller, 3: Pedestrian } \\
\text { with child, 4: Cyclist, } \\
\text { 5: Cyclist with child }\end{array}$ & $\begin{array}{l}1: 73.08 \%, \\
2: 9.23 \%, \\
3: 9.23 \%, \\
4: 7.69 \%, \\
5: 0.77 \%\end{array}$ & $\begin{array}{l}\text { Time_} \\
\text { Sav_B }\end{array}$ & $\begin{array}{l}\text { B- signalized } \\
\text { crossing, }\end{array}$ & $\begin{array}{l}\text { 1: A lot, } \\
\text { 2: A little, } \\
\text { 3: Moderate, } \\
\text { 4: Almost at } \\
\text { all, 5: At all }\end{array}$ & $\begin{array}{l}\text { 1: } 35.93 \%, \\
2: 28.90 \%, \\
3: 28.13 \%, \\
4: 3.91 \%, \\
5: 3.13 \%\end{array}$ \\
\hline
\end{tabular}




\begin{tabular}{|c|c|c|c|c|c|c|c|}
\hline Code & Description & Values & Measure & Code & Description & Values & Measure \\
\hline Mode_trsp & $\begin{array}{l}\text { Most used } \\
\text { daily mode of } \\
\text { transportation }\end{array}$ & $\begin{array}{l}\text { 1: Private car, } \\
\text { 2: Motorcycle, } \\
\text { 3: Bicycle, 4: Public } \\
\text { transportation, } \\
\text { 5: Walking, 6: Other }\end{array}$ & $\begin{array}{l}1: 31.54 \%, \\
2: 7.69 \%, \\
3: 7.69 \%, \\
4: 27.69 \%, \\
5: 24.62 \% \\
6: 0.77 \%\end{array}$ & $\begin{array}{l}\text { Time_Sav_ } \\
\mathrm{Fb}\end{array}$ & Footbridge & $\begin{array}{l}\text { 1: Alot, } \\
\text { 2: Alittle, } \\
\text { 3: Moderate, } \\
\text { 4: Almost at } \\
\text { all, 5: At all }\end{array}$ & $\begin{array}{l}1: 36.51 \%, \\
2: 10.32 \%, \\
3: 23.02 \%, \\
4: 17.45 \%, \\
5: 12.70 \%\end{array}$ \\
\hline Walk_trip & $\begin{array}{l}>10 \text { minutes } \\
\text { daily walking } \\
\text { trips }\end{array}$ & $\begin{array}{l}\text { 1: None, 2: One, } \\
\text { 3: Two, 4: Three, } \\
\text { 5: Four, 6: Five, 7: Six, } \\
\text { 8: Ten }\end{array}$ & $\begin{array}{l}1: 7.69 \%, \\
2: 12.31 \%, \\
3: 33.85 \%, \\
4: 16.92 \%, \\
5: 15.38 \%, \\
6: 6.92 \%, \\
7: 4.62 \%, \\
8: 2.31 \%\end{array}$ & Safety_A & $\begin{array}{l}\text { Safety when } \\
\text { crossing: } \\
\text { A- signalized } \\
\text { crossing, }\end{array}$ & $\begin{array}{l}\text { 1: Very, } \\
\text { 2: A little, } \\
\text { 3: Moderate, } \\
\text { 4: Almost at } \\
\text { all, 5: At all }\end{array}$ & $\begin{array}{l}1: 24.62 \%, \\
2: 28.46 \%, \\
3: 34.62 \%, \\
4: 8.46 \%, \\
5: 3.84 \%\end{array}$ \\
\hline Freq_A & $\begin{array}{l}\text { Frequency } \\
\text { of crossing: } \\
\text { A- signalized } \\
\text { crossing, }\end{array}$ & $\begin{array}{l}\text { 1: Every day, } \\
\text { 2: 2-3 times per } \\
\text { week, 3: Once per } \\
\text { week, 4: 1-2 times } \\
\text { per month, 5: Rarely, } \\
6: \text { Never }\end{array}$ & $\begin{array}{l}1: 11.63 \%, \\
2: 22.48 \%, \\
3: 8.53 \%, \\
4: 9.30 \%, \\
5: 17.83 \%, \\
6: 30.23 \%\end{array}$ & Safety_B & $\begin{array}{l}\text { B- signalized } \\
\text { crossing, }\end{array}$ & $\begin{array}{l}\text { 1: Very, } \\
\text { 2: Alittle, } \\
\text { 3: Moderate, } \\
\text { 4: Almost at } \\
\text { all, 5: At all }\end{array}$ & $\begin{array}{l}1: 32.03 \%, \\
2: 41.41 \%, \\
3: 21.88 \%, \\
4: 3.12 \%, \\
5: 1.56 \%\end{array}$ \\
\hline Freq_B & $\begin{array}{l}\text { B- signalized } \\
\text { crossing, }\end{array}$ & $\begin{array}{l}\text { 1: Every day, } \\
\text { 2: 2-3 times per } \\
\text { week, 3: Once per } \\
\text { week, 4: 1-2 times } \\
\text { per month, 5: Rarely, } \\
6: \text { Never }\end{array}$ & $\begin{array}{l}1: 15.38 \%, \\
2: 28.46 \%, \\
3: 14.62 \%, \\
4: 6.92 \%, \\
5: 16.93 \%, \\
6: 17.69 \%\end{array}$ & Safety_Fb & Footbridge & $\begin{array}{l}\text { 1: Very, } \\
\text { 2: Alittle, } \\
\text { 3: Moderate, } \\
\text { 4: Almost at } \\
\text { all, 5: At all }\end{array}$ & $\begin{array}{l}1: 87.30 \%, \\
2: 4.76 \%, \\
3: 3.17 \%, \\
4: 3.18 \%, \\
5: 1.59 \%\end{array}$ \\
\hline Freq_Fb & Footbridge & $\begin{array}{l}\text { 1: Every day, } \\
\text { 2: 2-3 times per } \\
\text { week, 3: Once per } \\
\text { week, 4: 1-2 times } \\
\text { per month, 5: Rarely, } \\
\text { 6: Never }\end{array}$ & $\begin{array}{l}1: 0.77 \%, \\
2: 5.38 \%, \\
3: 7.69 \%, \\
4: 6.92 \% \\
5: 30.00 \%, \\
6: 49.24 \%\end{array}$ & Distance & $\begin{array}{l}\text { Distance from } \\
\text { footbridge } \\
\text { affecting the } \\
\text { decision of } \\
\text { crossing point }\end{array}$ & $\begin{array}{l}\text { 1: Very, } \\
\text { 2: Alittle, } \\
\text { 3: Moderate, } \\
\text { 4: Almost at } \\
\text { all, 5: At all }\end{array}$ & $\begin{array}{l}1: 16.92 \%, \\
2: 16.92 \%, \\
3: 5.38 \%, \\
4: 10.00 \%, \\
5: 50.78 \%\end{array}$ \\
\hline Cross_sc & $\begin{array}{l}\text { Crossing } \\
\text { a signalized } \\
\text { crossing }\end{array}$ & $\begin{array}{l}\text { 1: During green light } \\
\text { phase, 2: During red } \\
\text { light phase, } 3 \text { : Any } \\
\text { time }\end{array}$ & $\begin{array}{l}\text { 1:76. } 92 \%, \\
2: 23.08 \%, \\
3: 0.00 \%\end{array}$ & Reasons & $\begin{array}{l}\text { Reasons of } \\
\text { using the } \\
\text { footbridge }\end{array}$ & $\begin{array}{l}\text { 1: Conveni- } \\
\text { ence in use, } \\
\text { time saving, } \\
\text { safety, } \\
\text { 2: Stroll, } \\
\text { 3: View, } \\
\text { 4: Pho- } \\
\text { tographs, } \\
\text { 5: Other }\end{array}$ & $\begin{array}{l}1: 60.00 \%, \\
2: 26.15 \%, \\
3: 8.46 \%, \\
4: 2.31 \%, \\
5: 3.08 \%\end{array}$ \\
\hline V_cross & $\begin{array}{l}\text { Variables } \\
\text { affecting } \\
\text { crossings }\end{array}$ & $\begin{array}{l}\text { 1: Traffic volume, } \\
\text { 2: Vehicles' speed, } \\
\text { 3: Number of } \\
\text { pedestrians waiting } \\
\text { the green light phase, } \\
\text { 4: Distance } \\
\text { from crosswalk, } \\
\text { 5: Pedestrians' } \\
\text { traffic light phase, } \\
\text { 6: Vehicles' traffic } \\
\text { light phase, } \\
\text { 7: Inability to see } \\
\text { passing vehicles }\end{array}$ & $\begin{array}{l}1: 18.10 \%, \\
2: 21.80 \%, \\
3: 2.70 \%, \\
4: 5.30 \%, \\
5: 42.60 \%, \\
6: 2.10 \%, \\
7: 7.40 \%\end{array}$ & & & & \\
\hline
\end{tabular}


crossing the bridge frequently in their everyday lives; those found at A- signalized crossing or B- signalized crossing do not use the footbridge often.

Significant correlations were found between the convenience and the frequency of crossing the footbridge. Interviewees perceiving high easiness $(\mathrm{r}=0.329, \mathrm{p}<0.05)$ and time saving $(\mathrm{r}=0.225$, $\mathrm{p}<0.05$ ) when using the footbridge tend to use it regularly. Interviewees stated that their distance from the footbridge affects their decision of the crossing point appear to use the signalized crossings frequently. Finally, the frequency of using the footbridge is associated with the reasons of crossing it, namely the convenience/time saving/safety, stroll, to take photographs of the nice view from the footbridge or other reasons.

\section{REGRESSION MODELLING}

The model developed aims to investigate which and to what extent factors affect the operation and the decision of crossing Megalou Alexandrou Avenue using the footbridge. The dependent variable chosen was the ordinal factor "Frequency in using the footbridge", hence the model built was an ordinal regression model. In ordinal regression model the event of interest is observing a particular score or less. For the case of the ordinal dependent variable "Frequency in using the footbridge" including $j=6$ categories the following odds are modeled:

$\theta_{i}=\operatorname{prob}($ score of $\mathrm{i}) / \operatorname{prob}($ score greater that $\mathrm{i})$, where $\mathrm{i}=\mathrm{j}-1$

The ordinal regression model for a single independent variable is then:

$\ln \left(\theta_{j}\right)=\alpha_{j}-\beta X$

The positive coefficient in the predictor variable, means that higher coefficients indicate an association with the first category of the dependent variable; the negative coefficient means lower coefficients indicate an association with the first category.

Due to the fact that SPSS software, used for creating the model, automatically uses the last class as a reference category when applying ordinal regression, it was deemed necessary to re-code the nominal and ordinal independent variables so that the reference category collects a relatively high number of re- sponses. Considering the literature review findings, inferential statistics results and several "try and error" tests, the variables shown in Table 3 were finally included in the model.

Table 3. Model variables and reference categories.

\begin{tabular}{ll}
\hline Variable & Reference Category \\
\hline $\begin{array}{l}\text { Frequency of crossing the } \\
\text { footbridge }\end{array}$ & - \\
Age of interviewee & $25-39$ \\
Easiness in using the footbridge & Very \\
$\begin{array}{l}\text { Time saving when crossing the } \\
\text { footbridge }\end{array}$ & A lot \\
$\begin{array}{l}\text { Distance from footbridge affecting } \\
\text { the decision of crossing point }\end{array}$ & At all \\
\begin{tabular}{l} 
Crossing point \\
\hline
\end{tabular} & B-signalized crossing \\
\hline
\end{tabular}

The overall fitting indicates table reveals that the proposed model fits the data well and it is appropriate for estimations. The Model Fitting Information indicates a statistical improvement; the performed test compares the -2LL of the baseline (intercept only) that do not contain any independent variables and the final model. The result of the p-value (Sig.<0.001) reveals a significant improvement as the final model is outperforming the Null. The Goodness-of- Fit suggests that the data are consistent with the model assumptions since the significance value ( $p$-value) is greater than 0.05 . The Nagelkerke R-Square reveals that the final model can explain approximately $41.6 \%$ of the variance. Finally, the Test of Parallel Lines indicates that the regression coefficients are not the same for all the six categories of the dependent variable ( $p$-value $<0.05$ ). Table 4 presents the overall fitting indicates.

Table 4. Overall fitting indicates for the ordinal model.

\begin{tabular}{lllll}
\hline Model Fitting Information & & & \\
\hline Model & $\begin{array}{l}\text {-2 Log } \\
\text { Likelihood } \\
\text { Intercept Only }\end{array}$ & $\begin{array}{l}\text { Chi- } \\
\text { Square }\end{array}$ & df & Sig. \\
Final & 239,948 & & & \\
\hline Goodness-of-Fit & & 60,869 & 22 &, 000 \\
\hline & Chi- & df & Sig. & \\
& Square & & & \\
Pearson & 383,764 & 386 &, 523 & \\
Deviance & 221,300 & 386 & 1,000 & \\
\hline
\end{tabular}




\begin{tabular}{ll}
\hline \multicolumn{2}{l}{ Pseudo R-Square } \\
\hline Cox and Snell &, 383 \\
Nagelkerke &, 416 \\
McFadden &, 189 \\
\hline
\end{tabular}

Test of Parallel Lines

\begin{tabular}{lllll}
\hline Model & $\begin{array}{l}-2 \text { Log } \\
\text { Likelihood }\end{array}$ & $\begin{array}{l}\text { Chi- } \\
\text { Square }\end{array}$ & df & Sig. \\
Null Hypothesis & 239,079 & & & \\
General & 179,765 & 59,314 & 66 &, 707 \\
\hline
\end{tabular}

The following Table 5 presents the parameter (beta) estimates, the standard error (S.E.), the Wald statistic, the significance level as well as the lower and the upper bound with 95\% confidence interval.

The ordinal regression model interpretation is based on the odd ratio results presented on Table 6 . The odds ratios results refer to significant correlations between the statistically significant intervals of independent variables (Sig. $<0,05)$ and their reference categories.

Table 5. Parameter estimates for the ordinal regression model.

\begin{tabular}{|c|c|c|c|c|c|c|c|c|}
\hline & & \multirow[b]{2}{*}{ Estimates } & \multirow[b]{2}{*}{ S.E } & \multirow[b]{2}{*}{ Wald } & \multirow[b]{2}{*}{ df } & \multirow[b]{2}{*}{ Sig. } & \multicolumn{2}{|c|}{ 95\% Confidence Interval } \\
\hline & & & & & & & Lower Bound & Upper Bound \\
\hline \multirow[t]{4}{*}{ Threshold } & {$[$ Freq_Fb $=2]$} & $-4,308$ & ,646 & 44,477 & 1 & ,838 &, 004 &, 048 \\
\hline & [Freq_Fb = 3] & $-3,052$ & ,533 & 32,807 & 1 & 15,186 &, 017 & ,134 \\
\hline & {$[$ Freq_Fb $=4]$} & $-2,469$ &, 511 & 23,348 & 1 & . &, 031 & ,230 \\
\hline & [Freq_Fb $=5]$ &,- 555 & ,459 & 1,459 & 1 & ,227 & ,234 & 1,412 \\
\hline \multirow[t]{23}{*}{ Location } & {$[\mathrm{Age}=1]$} &, 423 &, 521 & ,660 & 1 & ,416 &, 550 & 4,234 \\
\hline & {$[$ Age $=2]$} & 1,093 & 1,235 & ,783 & 1 & ,376 & ,265 & 33,571 \\
\hline & {$[\mathrm{Age}=3]$} &, 554 &, 627 & ,780 & 1 & ,377 & ,509 & 5,948 \\
\hline & {$[$ Age $=4]$} & 1,766 & ,741 & 5,684 & 1 & ,017 & 1,369 & 24,996 \\
\hline & {$[\mathrm{Age}=5]$} & $0 \mathrm{a}$ & . & . & 0 & . & . & . \\
\hline & [Easiness_Fb=1] & 3,098 & 1,435 & 4,663 & 1 & 031 & 1,331 & 368,340 \\
\hline & [Easiness_Fb $=2]$ & ,408 & ,750 & ,296 & 1 & ,586 & ,346 & 6,533 \\
\hline & [Easiness_Fb =3] &, 588 & ,608 & ,935 & 1 & ,334 & ,546 & 5,934 \\
\hline & [Easiness_Fb $=4]$ & 1,837 &, 881 & 4,353 & 1 & ,037 & 1,118 & 35,293 \\
\hline & [Easiness_Fb $=5]$ & $0 \mathrm{a}$ & . & . & 0 & . & . & . \\
\hline & [Time_Sav_Fb=1] & $-1,786$ & 1,036 & 2,970 & 1 & ,085 & ,022 & 1,278 \\
\hline & [Time_Sav_Fb $=2]$ &,- 831 & ,7338 & 1,284 & 1 & ,257 & ,103 & 1,834 \\
\hline & [Time_Sav_Fb $=3$ ] & $-1,258$ & ,625 & 4,056 & 1 & 044 & ,084 & ,967 \\
\hline & [Time_Sav_Fb $=4]$ & $-1,190$ & ,745 & 2,552 & 1 & ,110 & ,071 & 1,310 \\
\hline & [Time_Sav_Fb $=5]$ & $0 \mathrm{a}$ & . & . & 0 & . & . & . \\
\hline & [Distance_Fb=1] & ,402 & ,648 & ,386 & 1 & ,535 & ,420 & 5,324 \\
\hline & [Distance_Fb $=2]$ & $-1,340$ &, 542 & 6,115 & 1 & ,013 & ,091 & ,757 \\
\hline & [Distance_Fb $=3$ ] & $-2,003$ & ,877 & 5,224 & 1 & 022 & 024 & ,752 \\
\hline & [Distance_Fb $=4]$ & $-1,245$ & ,606 & 4,216 & 1 & 040 & ,088 & ,945 \\
\hline & [Distance_Fb $=5]$ & $0 \mathrm{a}$ & . & . & 0 & . & . & . \\
\hline & [Cross_point=1] &,- 430 & ,470 & ,838 & 1 & ,360 & 1,634 & 1,634 \\
\hline & [Cross_point =2] & -2.221 &, 570 & 15,186 & 1 &, 000 & ,332 & ,332 \\
\hline & [Cross_point $=3]$ & $0 \mathrm{a}$ & . & . & 0 & . & . & . \\
\hline
\end{tabular}

\footnotetext{
${ }^{a}$ Parameter is set to zero because it is redundant.
} 
Table 6. Odds ratio results.

\begin{tabular}{|c|c|c|}
\hline Variable & Intervals & Odds ratios \\
\hline \multirow[t]{2}{*}{ Age } & $55-64$ & \\
\hline & 25-39 (reference category) & 5,850 \\
\hline \multirow[t]{4}{*}{ Easiness_Fb } & At all & 22,143 \\
\hline & Very (reference category) & \\
\hline & Almost at all & 6,281 \\
\hline & Very (reference category) & \\
\hline \multirow[t]{2}{*}{ Time_Sav_Fb } & Moderate & 0,284 \\
\hline & A lot (reference category) & \\
\hline \multirow[t]{6}{*}{ Distance_Fb } & A little & 0,262 \\
\hline & $\begin{array}{l}\text { Not at all (reference } \\
\text { category) }\end{array}$ & \\
\hline & Moderate & 0,135 \\
\hline & $\begin{array}{l}\text { Not at all (reference } \\
\text { category) }\end{array}$ & \\
\hline & A lot & 0,288 \\
\hline & $\begin{array}{l}\text { Not at all (reference } \\
\text { category) }\end{array}$ & \\
\hline \multirow[t]{2}{*}{ Cross_point } & Footbridge & 0,108 \\
\hline & $\begin{array}{l}\text { B-signalized crossing } \\
\text { (reference category) }\end{array}$ & \\
\hline
\end{tabular}

The above table reveals that interviewees aged between 25-39 have almost 6 times greater possibility not to cross the footbridge in comparison to those aged 55-64 who cross the Avenue using the footbridge more often.

Concerning the easiness, interviewees stated that the footbridge is "very" easy to use present 22 times and 6 times higher possibility to use the footbridge, compared to those stated not "at all" and "almost at all" easy to use respectively. Additionally, pedestrians that perceived "a lot" time saving are more probable to use the footbridge in contrast to others stated "moderate" time saving.

Interviewees stated that the distance from the footbridge affects "a little" or "a lot" their decisionmaking present approximately 0,2 times higher possibility not to use the footbridge frequently, while pedestrians stated "moderate" have about 0,1 times greater possibility not to use the footbridge. Finally, interviewees located on the footbridge while filling the questionnaire meet approximately 0,3 times greater possibility of using the footbridge often, compared to interviewees located on B-signalized crossing.
The mathematical expression of the ordinal regression model and the determination of the frequency of crossing the footbridge is:

$\operatorname{Ln}($ Freq_Fb $)=1,766 *$ age_55-64 + easiness_fb_ at_all *3,098 + easiness_fb_almost_at_all *1,837time_sav_fb_Moderate *1,258-distance_fb_a_little $* 1,340-$ distance_fb_moderate $* 2,003-$ distance fb_a_lot* 1,245-Cross_point_footbridge * 2,221

It must be mentioned at this point that there is a big chance that repeating the study would result in another mathematical expression. Therefore, this mathematical expression must be treated with extreme caution.

\section{DISCUSSION AND CONCLUSIONS}

The authors of the paper strongly believe that pedestrian bridges, tunnels or crossing lights are an anomaly in city design; an ideal city should not need any of these elements. However, we have considered that it will be worthwhile to try to understand the pedestrians' point of view as far as a footbridge is concerned. We think that lessons learned must guide us in our future steps by avoiding possible unnecessary decisions. A footbridge should be constructed in a way that it does not impose extra burdens on the shoulder of the pedestrian, like insecurity, chance of sliding, tripping or falling, and should be suitable for people with a handicap.

The analysis of the collected questionnaires revealed that most of the interviewees, namely $87,3 \%$, describe the footbridge "very" safe to cross and $21,8 \%$ that the $60.61 \mathrm{~km} / \mathrm{h}$ vehicle speed affects their crossing behavior. Although based on the above evidence pedestrians were expected to use the footbridge to cross Megalou Alexandrou Avenue, according to the undertaken research $49.23 \%$ of the interviewees never cross it. The frequency of crossing the Avenue using the footbridge depends on pedestrians' age, their perception of easiness and time saving, their distance from the footbridge and finally the crossing point located.

Based on the literature review findings, pedestrians' distance from a footbridge in combination with the increase of the walking distance leads to longer path routes, thus encounter as reasons of not choosing the footbridge. Especially when signalized crossings are located nearby a footbridge, it seems that 
pedestrians tend to use level crossings. The present research confirms the above-mentioned fact as the ordinal model reveals that pedestrians taking under consideration the distance is more likely not to choose the footbridge but a signalized crossing instead. Greater distances lead to increase of the travel time requiring more effort hence affecting the easiness of use. Easiness in using a footbridge is a significant aspect affecting pedestrians' behavior. This research confirms that pedestrians who perceive the crossing of the footbridge very easy, use the footbridge frequently in their daily lives. Contrariwise, those who stated that the footbridge is not at all easy to use do often use the footbridge. The under-study footbridge is often considered by the pedestrians in the area as a "touristic attraction, a place with a nice view, a place where someone can take nice photographs". This has no consequences for the design of the specific footbridge. However, if such an attitude from the pedestrians could be anticipated, the design process of a pedestrian bridge could include elements to facilitate such visits. Moreover, this research substantiates the fact that when pedestrians perceive time saving in using the footbridge it is more likely to use the footbridge regularly. Additionally, the findings of the present research comply with the findings of the literature review, namely that choosing a footbridge over a signalized crossing is a habit and not a random act.

Although literature review suggests that personal safety is important, for the case of Megalou Alexandrou footbridge this coefficient is trivial. It is possible that pedestrians feel secure when crossing the footbridge due to its location near the city center of Thessaloniki and the high vehicle and pedestrian traffic flow in the coastal zone. Finally, age variable resulted in significant correlation with the frequency of using the footbridge. The ordinal regression model proved that older pedestrians choose the footbridge more frequently in contrast to younger ones.

Footbridge level of usage is not satisfying. Correctional interventions including bridge cleaning, construction maintenance and lighting installation may contribute to promoting its usage.

The undertaken research is subject to certain limitations. One of the basic limitations in the survey has to do with the absence of data concerning mobility restrictions. There was not any question included in the questionnaire-based survey about this important issue. The authors intent to focus on this issue in a future continuation of their research. Because this investigation concerns only one situation under one condition (footbridge also used by bicyclists, two signalized crossings), reliability as well as validity is at stake. For example, a question is whether repeating the study in other conditions (time of year and day, weather) would reveal the same results. We also don't know if the sample studied is representative for the population in this area. Therefore, the authors believe that this study can only be considered as an explorative study, to be followed by more studies, before firm conclusions can be drawn. Because most data are on nominal level, statistics has to be used with caution. Additionally, the ordinal regression model and the produced mathematical expression is applicable for the case of the footbridge located in Megalou Alexandrou Avenue. Footbridge's location, may result in different variables affecting the decision making of choosing a crossing point. A footbridge situated at a place other than the urban center may be addressed differently. Hence, the variables affecting the frequency of using a footbridge may vary as well.

The next steps could lift the existing constraints. Footbridge's constructional characteristics may affect pedestrians' decision of crossing it. The study of footbridges with elevators may alternate the results. The footbridge examined in the present research was situated between two signalized crossings. The absence of level crossings may boost the frequency of choosing a footbridge. Finally, studying the crossings during different weather conditions and time of the year may result in different interpretation.

The results presented in this paper, the methodology and the tools used, are of primary importance for policy makers and local authorities who already operate or are planning to operate a new footbridge. To have an efficiency investment, such as analysis regarding the targeted population as well as the interventions needed to increase the potential of walking should be carefully investigated.

In any case, the construction of a footbridge is a rather expensive option. Such a decision in terms of Cost-Benefit Analysis (CBA) has to take into account a number of quantitative (e.g. cost) and qualitative (e.g. comfort) factors. In addition, a Multiple-Criteria Decision Analysis (MCDA) must be performed including all possible stakeholders. The environmental evaluation of the impacts of a footbridge also plays a crucial role in any decision taken by the respective authorities. The design and implementation of Sustainable Urban Mobility Plans (SUMPs) 
offer the framework within which decision making and taking about the construction of a footbridge can be adequately examined and evaluated. Authorities need to formulate their strategies and policies about pedestrian infrastructure by considering first and above all the user needs (at this point, the use of stated and revealed preferences surveys is of great importance). It is well known that demand may never automatically appear in such an infrastructure unless the above-mentioned methodological steps were followed. There are basic questions need to be answered before any decision will be taken. Do we really need the footbridge? Who is going to use it? Why? How often? Under which preconditions? Do we firstly make an exhaustive analysis of alternative solutions in terms of sustainable mobility? The findings of this research can be used as input data to the provision of answers to the above-mentioned questions.

\section{REFERENCES}

Abojaradeh, M. (2013). Evaluation of Pedestrian Bridges and Pedestrian Safety in Jordan. Civil and Environmental Research, 3.

Anciaes, P. R., \& Jones, P. (2018). Estimating preferences for different types of pedestrian crossing facilities. Transportation Research Part F: Traffic Psychology and Behaviour, 52, 222-237. doi: https://doi.org/10.1016/j.trf.2017.11.025

Ausserer, K., \& Kaufmann, C. (2010). Once a walker always a walker or 'You can't teach an old dog new tricks'-results of a mobility study of pre-school children. Presentation at ICTCT 2010, Netherlands.

Cantillo, V., Arellana, J., Rolong, M. (2015). Modelling pedestrian crossing behaviour in urban roads: A latent variable approach. Transportation Research Part F: Traffic Psychology and Behaviour, 32, 56-67. doi: https://doi.org/10.1016/j. trf.2015.04.008

Chen, Z., Fan, W. (2019). A multinomial logit model of pedestrian-vehicle crash severity in North Carolina. International Journal of Transportation Science and Technology, 8, 43-52. doi: https://doi.org/10.1016/j.ijtst.2018.10.001

Cohen, B., A., Wiles, R., \& Campbell, C. (1997). Mean Streets: Pedestrian Safety and Reform of the Nation's Transportation Law. Washington, DC: Surface Transportation Policy Project.

Daniel, W.W. (1999). Biostatistics: A foundation for analysis in the health sciences. 7th Edition, John Wiley \&Sons, Inc., Hoboken. doi: https://doi.org/10.1002/10970258(20010130)20:2<324::AID-SIM635>3.0.CO;2-O

D’ Andrea, A., Carbone, F., Salviera, S., Pellegrino, O. (2012). The most influential variables in the determination of V85 speed. Procedia- Social and Behavioral Sciences, 53, 633- 644. doi: https://doi.org/10.1016/j.sbspro.2012.09.913
Europa Eurostat. Road accident fatalities - statistics by type of vehicle.

Farmer, M., C. (2016). Relationship of traffic fatality rates to maximum state speed limits. Traffic Injuryand Prevention, 18, 375-380. doi: 10.1080/15389588.2016.1213821

Feliciani, C., Gorrini, A., Crociani, L., Vizzari, G., Nishinari, K., Bandini, S. (2020). Calibration and validation of a simulation model for predicting pedestrian fatalities at unsignalized crosswalks by means of statistical traffic data. Journal of Traffic and Transportation Engineering, 7, 1, 1-18. doi: https://doi. org/10.1016/j.jtte.2019.01.004

FHWA, Federal Highway Administration, (2006). How to Develop a Pedestrian Safety Action Plan. Final Report

Fossum, M., \& Ryeng, E. (2019). Pedestrians' route choice during winter conditions. Presentation at ICTCT 2019, Warszawa.

Híjar, M., Vazquez-Vela, E., Arreola-Risa, C. (2003). Pedestrian traffic injuries in Mexico: a country update. Injury Control and Safety Promotion, 10, 37-43. doi: https://doi.org/10.1076/ icsp.10.1.37.14108

Hussain, Q., Feng, H., Grzebieta, R., Brijs, T., Olivier, J. (2019). The relationship between impact speed and the probability of pedestrian fatality during a vehicle-pedestrian crash: A systematic review and meta-analysis. Accident Analysis \& Prevention, 129, 241-249. doi: https://doi.org/10.1016/j. aap.2019.05.033

IBM SPSS ${ }^{\circledR}$ software, https://www.ibm.com/analytics/spssstatistics-software

ITE, Institute of Transportation Engineers, (1998). Design and safety of pedestrian facilities. TENC-5A-5, ITE, Washington DC.

Kim, K., Made Brunner, I., Yamashita, E. (2008). Modeling violation of Hawaii's crosswalk law. Accident Analysis \& Prevention, 40, 894-904. doi: http://dx.doi.org/10.1016/j. aap.2007.10.004

Landa-Blanco, M., \& Ávila, J. (2020). Factors related to the use of pedestrian bridges in university students of Honduras. Transportation Research Part F: Traffic Psychology and Behaviour, 71, Pages 220-228, doi: https://doi.org/10.1016/j. trf.2020.04.016.

Mitsutaka, K., \& Toshikazu, Y. (2004). An observational study of the illegal crossing behavior of pedestrians: focusing on the effects of hurrying and habit. Jpn. J. Social Psychol. 19, 234-240. doi: https://doi.org/10.14966/jssp.KJ00003724917

Moore, R. L. (1953). Pedestrian choice and judgment. Operational Research Quarterly, 4, 3-10. doi: https://doi.org/10.1057/ jors.1953.2

Moore, R. L., \& Older, S. J. (1965). Pedestrians and Motors are Compatible in Today's World. Traffic Engineering, Institute of Transportation Engineers, 35.

Naing, L., Winn, T., \& Rusli, B.N. (2006). Practical issues in calculating the sample size for prevalence studies. Archives of Orofacial Sciences, 1, 9-14.

NHTSA, National Highway Traffic Safety Administration (2015). Traffic safety facts. Washington DC. Retrieved from https://www.nhtsa.gov/road-safety 
Oviedo-Trespalacios, O., \& Scott-Parker, B. (2017). Footbridge usage in high-traffic flow highways: The intersection of safety and security in pedestrian decision-making. Transportation Research Part F: Traffic Psychology and Behaviour, 49, 177-187. doi: https://doi.org/10.1016/j.trf.2017.06.010

Pucher, J. \& Dijkstra, L. (2003). Promoting safe walking and cycling to improve public health: lessons from The Netherlands and Germany. A Publication of the American Public Health Association, 93, 1509-16. doi: 10.2105/ajph.93.9.1509.

Räsänen, M., Lajunen, T., Alticafarbay, F., Aydin, C. (2007). Pedestrian self-reports of factors influencing the use of pedestrian bridges. Accident Analysis \& Prevention, 39, 969-973. doi: http://dx.doi.org/10.1016/j.aap.2007.01.004

Richards, D. (2010). Relationship between Speed and Risk of Fatal Injury: Pedestrians and Car Occupants. Road Safety Web Publication No. 16

Rosenbloom, T. (2009). Crossing at a red light: behaviour of individuals and groups. Transportation Research Part F: Traffic Psychology and Behaviour, 12, 389-394. doi: https://doi. org/10.1016/j.trf.2009.05.002

Sangphong, O., \& Siridhara, S. (2014). A Study of Footbridge Utilization Behavior in Nakhon Ratchasima. Review of Integrative Business \& Economic Research, 3 (NRRU). Retrieved from https://sibresearch.org/uploads/2/7/9/9/2799227/riber_h14104_93-100.pdf

Shatu, F., Yigitcanlar, T., Bunker, J. (2019). Shortest path distance vs. least directional change: Empirical testing of space syntax and geographic theories concerning pedestrian route choice behaviour. Journal of Transport Geography, 74, 37-52. doi: https://doi.org/10.1016/j.jtrangeo.2018.11.005.

Sinclair, M., \& Zuidgeest, M. (2016). Investigations into pedestrian crossing choices on Cape Town freeways. Transportation Research Part F: Traffic Psychology and Behaviour, 42, 479-494. doi: https://doi.org/10.1016/j.trf.2015.07.006

Statistic evidence Greek Traffic Police, http://www.astynomia. gr/index.php?option=0zo_content\&perform=view\&id=81\&It emi d=73\&lang=Thessaloniki, https://civitas.eu/content/thessaloniki

Wu, Y., Lu, J., Chen, H., Wu, L. (2014). Identification of contributing factors to pedestrian overpass selection. Journal of Traffic and Transportation Engineering, 1, 415-423. doi: https://doi. org/10.1016/S2095-7564(15)30291-9

Xu, J., Ge, Y., Qu, W., Sun, X., Zhang, K. (2018). The mediating effect of traffic safety climate between pedestrian inconvenience and pedestrian behavior. Accident Analysis \& Prevention, 119, 155-161. doi: https://doi.org/10.1016/j.aap.2018.07.020

Yordphol, T. \& Qian, J. (1994). Chinese Pedestrians and Their Walking Characteristics: Case Study in Beijing. Transportation Research Record, 1441, 16-26. Retrieved from http://onlinepubs.trb.org/Onlinepubs/trr/1994/1441/1441-003.pdf

Zacharias, J. (2001). Pedestrian behavior and perception in urban walking environments. Journal of Planning Literature, 16. doi: https://doi.org/10.1177/08854120122093249 